FACTA UNIVERSITATIS

Series: Economics and Organization Vol. 17, N ${ }^{\mathrm{o}} 1,2020$, pp. 57 - 68

https://doi.org/10.22190/FUEO191006005B

Original Scientific Paper

\title{
BOARD STRUCTURE AND BANK PERFORMANCE: EVIDENCE FROM SERBIAN BANKING SECTOR
}

\author{
UDC 336.7(497.11)
}

\author{
Verica Babić, Jelena Nikolić, Marijana Simić \\ University of Kragujevac, Faculty of Economics, Serbia
}

\begin{abstract}
Traditional perspective relying on agency theory is based on the assumption that the board structure, as an internal corporate governance mechanism, determines board effectiveness and, therefore, financial performance. Board size, board composition and leadership structure are distinguished as relevant variables of the board structure. Since the results of previous empirical studies are often contradictory, examining the correlation between board structural characteristics and corporate performance is a relevant research question, particularly in banking sector. In order to improve effectiveness of internal corporate governance mechanism, and consequently bank performance, the main research objective is to identify the impact of the board size and the board composition on bank performance in the Republic of Serbia using the CAMELS model. We analyze this relation using Ordinary Least Squares regression analysis on balanced panel data-set of 54 observations. The paper contributes to recent research efforts by making conclusions on the effects of board structure on bank performance, in order to define recommendations for improving performance in banking sector.
\end{abstract}

Key words: board of directors, board structure, performances, CAMELS, banking sector, Republic of Serbia

JEL Classification: G21, L21, O16

\section{INTRODUCTION}

Starting from the distinction between financial and non-financial sector (De Haan \& Vlahu, 2016), banks as financial institutions have a unique role in financial mediation and take an important position within the payment system (Flannery, 1998). Insufficient transparency, information asymmetry, complexity of bank business (Levine, 2004), high

Received October 6, 2019 / Accepted January 13, 2020

Corresponding author: Marijana Simić

University of Kragujevac, Faculty of Economics, Liceja Kneževnine Srbije 3, 34000 Kragujevac, Serbia

E-mail: msimic@kg.ac.rs 
debt ratio, as well as the problems of liquidity and solvency indicate the wide range of problems which banks have been facing, and which consequently reflects on the growth and development of economy (Macey \& O'Hara, 2003). In accordance with the above stated, the good practice of corporate governance and effective corporate control mechanisms represent necessary assumptions for the improvement of bank performances, by which negative effects of financial crisis and turbulent economic ambient can be mitigated (Beltratti \& Stulz, 2012; Erkens et al., 2012; Jackowicz \& Kowalewski, 2012). Thus, the development of good practice of corporate governance represents one of the key challenges for the creator of economic policy since the choice of corporate governance model depends on economic, social, technologic and political factors (Orazalin et al., 2016).

In accordance with the above mentioned, in transition economies, the selection of appropriate corporate governance model, as well as the effectiveness of corporate control mechanisms represent an important research field. The board of directors (i.e. board) as internal mechanism of corporate control has a significant role, due to which the research of board effectiveness is of special importance for the improvement of bank performance. According to the traditional research perspective, board size, board composition and board leadership structure represent relevant structural characteristics. Since structural characteristics determine board effectiveness, and consequently bank performances as well, the examination of relationship among these variables is a relevant research issue. However, the results of empirical studies are often contradictory, due to which general conclusions on the influence of board structural characteristics on bank performances cannot be derived.

In the previous empirical studies, two research directions can be singled out. The first research direction confirms negative influence (e.g. Staikouras et al., 2007; Pathan, 2009; Stančić et al., 2014), while the second research direction confirms positive influence of board structure on bank performances (e.g. Aebi et al., 2012; Adams \& Mehran, 2012; Minton et al., 2011), which implies the need for further research in this field. Since in the Republic of Serbia the empirical studies in the field of corporate governance, i.e. corporate control mechanisms are rare and sporadic, the need for the research of the influence of board structure on bank performance is even greater.

In order to overcome this research gap, the pilot research based on the sample which included 18 of total of 27 banks was conducted as a starting basis for future research. The contribution of the conducted research is reflected in making conclusion that can be guidelines for the development of good practice of corporate governance in banking sector, particularly in the process of nomination and selection of board members.

\section{LITERATURE REVIEW}

\subsection{Board structure in banking sector}

The roles of the board of directors can be observed through the perspective of different theories of corporate governance (e.g. agency theory, stakeholder theory, stewardship theory, resource dependence theory). According to the agency theory as the representative of conflict theories (Babic et al., 2011), the separation of ownership from control leads to the conflict of interest between the owners as principals and managers as agents. Starting from the identified agency problem (Kostyuk, 2011), and for the purpose of mitigation of the principal-agent conflict and the prevention of managerial opportunism, Fama and Jensen (1983) emphasize that monitoring and control of managerial decisions are a basic 
role of the board of directors. Moreover, the board of directors has the responsibility to make decisions that refer to the choice and the substitution of managers, formulation of compensation package, as well as the control of management team (Jadah \& Adzis, 2016). In line with the development of consensus theories (stakeholder theory, stewardship theory, resource dependence theory), the relevance of strategic board role (Babic et al., 2011) and directors' active participation in making strategic decisions is implied, highlighting the protection of interest, not only of shareholders, but also of other stakeholders. The board of directors has the responsibility that can be observed through the strategic decision making process and the initiation, evaluation and implementation of strategic decisions (BarrosoCastro, Perinan, \& Dominguez, 2017). The strategic participation of the board members considers their role in strategy formulation and implementation process, and not only in evaluating and approving the strategy (Pugliese, Bezemer, Zattoni, Huse, Van den Bosch, \& Volberda, 2009). According to the relevance of the control and strategic board role for improving performance, board effectiveness is an important area of research. Having in mind that board effectiveness represents the degree in which the activities encompassed by defined roles are successfully realized, it is possible to separate the two research perspectives: traditional and behavioral (Babić et al., 2012).

According to the traditional perspective, board size, board composition and the leadership structure analyzed through the duality in CEO position and chairperson are singled out as relevant variables of board structure (Jensen, 1993). Board size represents the total number of board members, who have the right to vote (Ongore et al., 2014). It is often stated that the optimal size of bank board of directors implies the appointment of between 16 and 18 members, while the percentage of independent board members is in the range of $70 \%$ and $85 \%$, which is also larger than the average percentage of independent board members in non-financial corporations (60\%-70\%) (De Andres et al., 2012). Apart from board size, an important structural characteristic is board composition (Carteret al., 2003) which represents the relationship between the number of non-executive, independent directors and the total number of directors (Aebi et al., 2012; Erkens et al., 2012). In order to determine optimal number of independent directors, it is necessary to define primarily the criteria that determine members' independency. It is considered that a director, as a board member, is connected to a certain bank if he is: (1) a dominant owner; (2) a bank employee; (3) an employee in any company or company branch that is above certain bank on the ownership tree; (4) an employee in other company in which dominant shareholder has at least $10 \%$ of voice rights, regardless whether this company is on the same ownership tree; (5) a politician or employee in the government agency, when the dominant stakeholder is government; or (6) a company worker that is in the same country, where dominant stakeholder is from, when dominant stakeholder is a foreign citizen. On the other hand, directors that do not satisfy any of the mentioned criteria, are considered to be independent members (Stančić et al., 2014).

The leadership structure can be defined as the duality of CEO position and chairperson. The key dilemma is whether the positions should be unified or separated, or whether the CEO and chairperson's roles should be combined in one person or not (Babić et al., 2012). In fact, two opposite opinions can be singled out. Firstly, the separation of the positions of CEO and chairperson implies the reduction of agency expenses. On the other hand, the unification of the positions is described in terms of the power concentrated in one person's hands that allows CEO to control the information that is available to the other board members. 


\subsection{Bank performance}

The measurement of financial performances of banks is of great significance for both internal and external users, among which are managers, depositors, creditors, investors, employees and regulators, since their expectations and interests are often different. The bank has to reach a short-term maximization of profit, which is often measured by the rate of return on equity (ROE), the rate of return on assets (ROA) or by the net interest margin (NIM). However, as in the case of non-financial corporations, the main objective is long-term profitability, which is usually measured by earnings per share (EPS) or by market price per share (MPS) (Belkhir, 2009; Orazalin et al., 2016).

Most of the studies carried out in emerging countries are focused on the monitoring of traditional accounting measures of bank performances, such as return on assets (ROA) and return on equity (ROE). Furthermore, in order to determine the relation between corporate governance and performances, Tobin's q and other market measures of bank performances are used as relevant indicators. Starting from the fact that the capital market in Serbia is insufficiently developed and non-efficient, as the information from the market is often unreliable, the problems with calculating mentioned indicators are the main reason for rare use of market performance indicators. Due to previous empirical results and limitations, it is necessary to include bank-specific performance indicators, such as the growth of assets, liquidity, and the quality of governance and capital adequacy (CAPAD).

Respecting the mentioned characteristics of banking sector, the internal methods of measuring performances are developed, such as the analysis of financial ratios, data envelopment analysis (DEA) and CAMELS model (Desta, 2016). CAMELS model, as one of the most famous models, is based on the evaluation of capital standards, quality of assets, management, earning capacity, liquidity and sensitivity to market risk of bank institutions. The acronym CAMELS is derived on the basis of the name of components that are used as specific financial indicators: capital adequacy, assets quality, management efficiency, earning capacity, liquidity and sensitivity to market risk (Dang, 2011; Desta, 2016; Vunjak et al., 2012). First of all, the implementation of this methodology considers the calculation of corresponding ratio indicators using the data published in the financial reports, such as balance sheet, income statement, and balance of cash flows. On the basis of conducted analysis, interested parties are expected to undertake necessary reactive and proactive measures towards providing bank prosperity as well as the efficiency of banking sector.

\subsection{Board structure and bank performance}

In numerous empirical studies, the correlation between board structural characteristics and bank performances is articulated in opposing ways, due to the fact that it is not possible to make a general conclusion on the intensity and direction of identified impact. In addition, the research results in transitional countries have shown bigger heterogeneity.

In the case of correlation between board size and bank performance, the results of empirical studies are contradictory. Certain researches show that the increase of the number of board members implies more effective board role, i.e. service and control role (Jadah \& Adzis, 2016). Moreover, it is confirmed that larger number of board members can have positive influence on the performance of analyzed banks (Adams \& Mehran, 2012; Aebi et al., 2012). However, a larger number of board members lead to the problems of coordination and communication within organization (Cerbioni \& Parbonetti, 2007; Bushman et al., 2004). 
Lipton and Lorsch (1992) indicate that the board with more than 10 members can face the problem in expressing opinion and attitudes; that is why the innovation capability is limited. In addition, the process of making decisions in case of large boards is often less efficient, which affects their ability of identifying and exploitation of new business opportunity (Bantel \& Jackson, 1989). Consequently, larger number of board members is negatively related to corporate performance (Lipton \& Lorsch, 1992; Jensen, 1993; Yermack, 1996; Eisenberg et al., 1998). According to the above mentioned, the following hypothesis is defined:

H1. The board size negatively affects bank performances.

The empirical research results related to the effects of board composition on bank performances are mixed. One group of empirical studies is based on the stewardship theory, according to which managers act in the interest of owners, due to which it is desirable for the boards to be composed of large number of internal, executive directors. Since board effectiveness is observed through the degree of fulfillment of strategic board role, dominant participation of internal, executive directors make available the large amount of relevant information, knowledge and skills necessary for making strategic decisions (Babić et al., 2011). Consequently, the assumptions about the number of independent members are different depending on the perceived board role. Although, starting from the opinion that independent directors perform effective and objective control of managers which contributes to the reduction of agency costs (Borokhovich et al., 1996; Singh \& Davidson, 2003), positive influence of independent board composition on bank performances is supposed (Daily \&Dalton, 1992; Shungu et al., 2014; Jadah \& Adzis, 2016). According to the above mentioned, the following hypothesis is defined:

$\mathrm{H} 2$. The number of independent directors positively affects bank performances.

\section{MeTHODOLOGY}

\subsection{Research model and variables}

For the purpose of empirical testing of previous hypothesis, the research model has been developed (Figure 1) and both independent and dependent research variables have been defined.

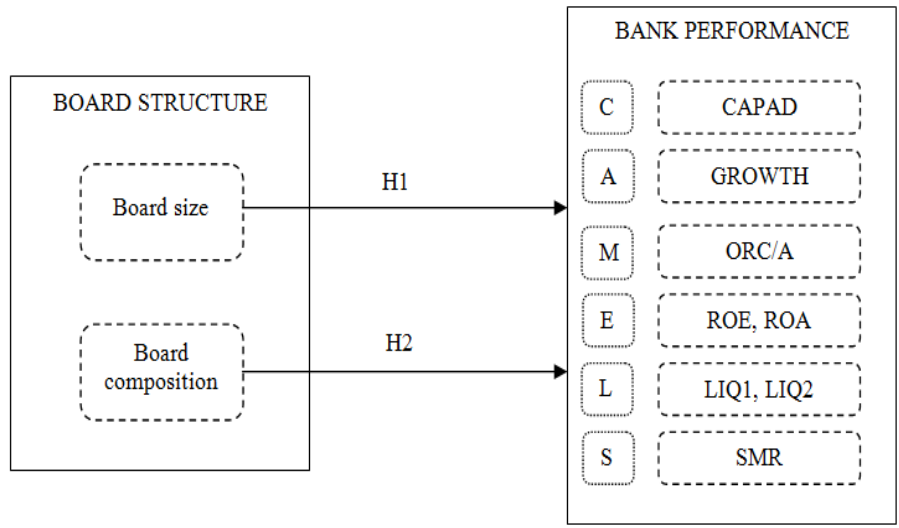

Fig. 1 Research model Source: Authors 
Starting from the presented research model, board size measured through the number of directors and board composition, observed through the number of independent directors as the key structural characteristics that determine board effectiveness, represent independent variables. According to the Law on Banks, the duality of CEO position and chairperson is not possible so the leadership structure is not incorporated in the research model (Table 1).

Table 1 Independent variables

\begin{tabular}{lll}
\hline Variables & Acronym Operationalization \\
\hline Board size & BDS & Total number of board members \\
Board composition & BDC & Number of independent directors divided by total number of directors \\
\hline \multicolumn{2}{c}{ Source: Authors }
\end{tabular}

In order to carry out the analysis of bank performances as dependent variables, the information from the bank financial reports has been collected. Pursuant to collected information the appropriate CAMELS indicators have been calculated. For each of the mentioned components of CAMELS models, at least one indicator has been calculated. The review of indicators, and their calculation is given in Table 2.

Table 2 Dependent variables

\begin{tabular}{|c|c|c|c|}
\hline CAMELS label & Variables & Acronym & Calculation \\
\hline Capital & Capital reserve ratio & CAPAD & $\begin{array}{l}\text { Total capital divided by total } \\
\text { assets }\end{array}$ \\
\hline Asset & Annual asset growth ratio & GROWTH & $\begin{array}{l}\text { (Total assets in year } 2-\text { total } \\
\text { assets in } 1) / \text { total asset in y } 1\end{array}$ \\
\hline Management & Operating expenses ratio & ORC/A & $\begin{array}{l}\text { Operating expenses divided by } \\
\text { total assets }\end{array}$ \\
\hline \multirow[t]{2}{*}{ Earning } & Return on Equity & ROE & $\begin{array}{l}\text { Earnings after tax divided by total } \\
\text { equity of the bank }\end{array}$ \\
\hline & Return on Assets & ROA & $\begin{array}{l}\text { Earnings after tax divided by total } \\
\text { assets of the bank }\end{array}$ \\
\hline \multirow[t]{2}{*}{ Liquidity } & Total loans ratio & LIQ1 & Total loans divided by total assets \\
\hline & Loan to deposit ratio & LIQ2 & $\begin{array}{l}\text { Total loans divided by total } \\
\text { deposits }\end{array}$ \\
\hline $\begin{array}{l}\text { Sensitivity } \\
\text { to market risk }\end{array}$ & Market risk sensitivity coefficient & SMR & Securities divided by total assets \\
\hline
\end{tabular}

\subsection{Sample}

Empirical research is carried out on the sample of 18 banks in the Republic of Serbia. The sample size is relevant, bearing in mind frequent change of the financial market structure which results in numerous mergers and acquisitions. Consequently, the number of banks that actively operate in the Republic of Serbia is constantly changing. Furthermore, it 
is important to emphasize that the participation of foreign banks in this sector significantly increased in the previous period. Based on this view, monitoring board structure and measuring financial bank performance is limited, especially in case of collecting data for longer period of time.

Since the stated variables are observed in three-year time interval from 2015 to 2017, the total number of observations is 54 , which represents good starting basis for implemented pilot testing. Pursuant to the provisions of the Law on Banks, banks are obliged to publish annual statements on business as well, apart from regular financial statements at quarterly and annual level. Thus, for the purpose of testing defined hypotheses, the data published in previously mentioned reports are used, while the data on board structure are collected on the basis of information that is collected at the web site of the National Bank of Serbia.

\section{RESULTS AND DISCUSSION}

The research results are shown via descriptive statistics, correlation matrix and regression panel model. All the descriptive statistics are reported in Table 3. On the basis of these results, it can be concluded that the average board size of analyzed banks is approximately 6 members in the observed time period, while the percentage of independent board members is in the interval from $37,1 \%$ to $41,2 \%$. As regards the bank performance indicators, the least average value refers to profitability indicators, i.e. in return rate on total assets. The heterogeneity of analyzed variables, identified on the basis of standard deviation, is the lowest in the case of board composition $(0,077 ; 0,079 ; 0,091$; respectively).

Table 3 Descriptive statistics (2015-2017)

\begin{tabular}{lcccccccccc}
\hline & BDS & BDC & CAPAD GROWTH ORC/A & ROA & ROE & LIQ1 & LIQ2 & SMR \\
\hline \multicolumn{10}{c}{ Mean } \\
\hline 2015. & 6,333 & 0,409 & 0,226 & 0,038 & 0,050 & $-0,015$ & 0,025 & 0,617 & 0,880 & 0,156 \\
2016. & 6,222 & 0,412 & 0,248 & 0,066 & 0,050 & $-0,004$ & 0,017 & 0,621 & 0,816 & 0,177 \\
2017. & 6,111 & 0,371 & 0,263 & 0,175 & 0,043 & 0,113 & 0,119 & 0,634 & 0,813 & 0,167 \\
\hline \multicolumn{10}{c}{ Standard deviation } \\
\hline 2015. & 1,328 & 0,077 & 0,149 & 0,105 & 0,021 & 0,067 & 0,158 & 0,154 & 0,311 & 0,122 \\
2016. & 1,555 & 0,079 & 0,121 & 0,097 & 0,025 & 0,053 & 0,178 & 0,153 & 0,221 & 0,140 \\
2017. & 1,451 & 0,091 & 0,119 & 0,354 & 0,019 & 0,097 & 0,202 & 0,136 & 0,267 & 0,121 \\
\hline \multicolumn{10}{c}{ Source: Authors }
\end{tabular}

Based on the application of Pearson correlation coefficient, the correlation analysis has been carried out. According to the results shown in Table 6, it is possible to conclude that between certain variables the significant correlation has been identified. Significant values are between 0,259 and 0,423, which imply weak to moderate correlation intensity. The largest correlation intensity is established between board size and coefficient that measures the sensitivity to market risk, while other significant values of Pearson coefficient are negative. 
Table 4 Correlation analysis: Pearson correlation coefficient

\begin{tabular}{|c|c|c|c|c|c|c|c|c|c|c|}
\hline & 1 & 2 & 3 & 4 & 5 & 6 & 7 & 8 & 9 & 10 \\
\hline 1 & 1 & & & & & & & & & \\
\hline 2 & $0,677^{* *}$ & 1 & & & & & & & & \\
\hline 3 & 0,128 & 0,032 & 1 & & & & & & & \\
\hline 4 & $-0,135$ & $-0,155$ & 0,029 & 1 & & & & & & \\
\hline 5 & 0,124 & 0,081 & $0,272^{*}$ & $-0,059$ & 1 & & & & & \\
\hline 6 & $-0,067$ & $0,287^{*}$ & $-0,298^{*}$ & 0,001 & $-0,308^{*}$ & 1 & & & & \\
\hline 7 & $-0,269^{*}$ & $-0,149$ & $-0,036$ & 0,081 & $-0,254$ & $0,319^{*}$ & 1 & & & \\
\hline 8 & $-0,411^{* *}$ & $-0,128$ & $-0,395^{* *}$ & 0,003 & $-0,029$ & 0,246 & $0,406^{* *}$ & 1 & & \\
\hline 9 & $-0,368^{\text {*** }}$ & $0,023^{*}$ & $-0,434^{* *}$ & $-0,109$ & $-0,026$ & 0,107 & $0,302^{*}$ & $0,876^{* *}$ & 1 & \\
\hline 10 & $0,423^{* * k}$ & 0,150 & $0,360^{* *}$ & 0,025 & $-0,136$ & $-0,074$ & $-0,274^{*}$ & $-0,912^{* *}$ & $-0,851^{* *}$ & 1 \\
\hline
\end{tabular}

Note: 1- BDS, 2- BDC, 3- CAPAD, 4- GROWTH, 5- ORC/A, 6- ROA, 7- ROE, 8- LIQ1, 9- LIQ2, 10- SMR

For the purpose of testing defined hypotheses, the regression panel analysis has been carried out. In order to develop adequate regression panel model, as well as to determine whether individual effects in random effects model are fixed or stochastic, Hausman's specification test has been used. Since this value is above the level of 0,1 , the conclusion is drawn that individual effects are stochastic, according to which the appropriate Random-effects model is created.

Table 5 Panel Regression Analysis (Cross-section random effects)

\begin{tabular}{|c|c|c|c|c|}
\hline Variables & \multicolumn{2}{|c|}{ ROA LIQ1 } & LIQ2 & SMR \\
\hline BDS & 0.012275 & $-0.037299^{* * *}$ & $-0.100815^{* * *}$ & $-0.032872^{* * *}$ \\
\hline $\mathrm{BDC}$ & $0.058034^{* *}$ & 0.022156 & $0.105507^{* *}$ & -0.012109 \\
\hline $\mathrm{R}^{2}$ & 0.117449 & 0.086598 & 0.154116 & 0.093348 \\
\hline Adjusted $\mathrm{R}^{2}$ & 0.082839 & 0.050779 & 0.120944 & 0.057793 \\
\hline F-statistic & $3.393500^{* *}$ & $2.417618^{*}$ & $4.645977^{* *}$ & $2.625443^{*}$ \\
\hline
\end{tabular}

According to the presented values of $\beta$ coefficient, that reflects the direction and intensity of the impact of independent on dependent variable, it can be concluded that the analyzed structural board characteristics have the influence on certain bank performances.

Regarding the influence of board size on bank performances, negative effect on liquidity indicators has been found (LIQ1, LIQ2) and sensitivity to market risk (SMR). The obtained result is in accordance with the previous empirical studies that were carried out by Eisenberg, Sundgren and Wells (1998), Yermack (1996) and Staikouras et al. (2007). According to the presented results, the improvement of bank performances can be reached through defining standards that refer to decreasing board size. The conclusion can be drawn that the increase of board size leads to the decrease of board effectiveness and causes problems in communication and coordination which, consequently, limits bank ability to deal with market risks.

Although most of empirical studies do not confirm significant influence of independent board on bank performances, the results presented in this paper have implied the existence of positive influence of the number of independent board members. In particular, positive significant influence of mentioned structural board characteristic has been confirmed on the 
return of assets (ROA), which is in accordance with the results of previous empirical studies, that were carried out by De Andres and Vallelado (2008) and Staikouras et al. (2007). Furthermore, similar result was also found in the case of liquidity analysis. Thus, board composition represents relevant question in the area of corporate governance in banking sector. In general, it can be highlighted that independent board members are more objective, especially when it comes to control board role.

\section{LIMITATIONS AND DIRECTIONS FOR FUTURE RESEARCH}

Apart from the significant implications of our studies in terms of improving board effectiveness, the carried research has a few limitations. The first limitation refers to the sample size. The data used for the analysis have been obtained on the basis of information that banks publish in their business reports, as well as publically available financial statements at the website of the National Bank of Serbia. Initially, the sample covered 27 banks in total, according to the latest data available at the website of the National Bank of Serbia. However, in order to create research model, it was necessary to collect data on board structure and performances in time interval from 2015 to 2017. Due to the problem of nontransparency of data and noncompliance, as well as to the growing trend of mergers and acquisitions, the sample covered 18 banks that actively operate in the observed period.

The second potential limitation refers to the period from 2015 to 2017 comprising 54 bank-year observations. Period from 2015 to 2017 may be short, regarding the nature of the observed dependent and independent variables. However, longer period has caused the decrease of the number of banks included in the sample. Consequently, the number of observations in regression model would be decreased as well, due to limited data transparency on bank performance in the available reports.

The third limitation represents the choice of dependent variables, i.e. bank performance indicators. Although the wide specter of bank performance indicators has been incorporated, not all regression models are of adequate validity, due to which only the results that are statistically significant have been presented in the paper. However, from this point of view, the application of CAMELS model has certain advantages. Basic advantage is reflected in using specific bank performance indicators, as well as the fact that rare empirical research has been based on the mentioned model, due to which obtained results represent useful framework for future research.

Possible direction of future research refers to the increase of observation number. Larger number of observations refers to the inclusion of other banks within financial sector, as well as the expanding of time period within which the empirical research would be carried out. Since human and social capital of board members affects the board effectiveness, the comprehensive research of board effectiveness based on the analysis of behavioral characteristics of board members, as well as their competences should be conducted.

\section{CONCLUSIONS}

The improvement of the effectiveness of corporate governance mechanisms has an important role not only in financial, but also in the entire economic system of one country. In banking sector, regulatory framework and board of directors are stated as the 
main mechanisms of corporate governance. An effective regulatory and institutional framework represents one of the key preconditions of economic growth and improvement of corporate governance mechanisms, especially when it comes to transitional economies. Furthermore, pursuant to the provisions of the Law on Banks, the board of directors is entitled responsibility for bank governance.

In order to provide an effective board, it is necessary to identify the factors that determine the board roles, and consequently bank performances, as well. In accordance with the mentioned, two hypotheses have been set out in the paper. The first hypothesis refers to the study of influence of board size on bank performances, measured through CAMELS model indicators. The reported results have shown that in the case of analyzed banks, board size has negative effect to bank performances, such as liquidity and sensitivity to market risk, whereby the mentioned structural characteristic has no significant influence on other observed bank performance indicators. The other hypothesis is set out in order to establish whether there is positive, statistically significant influence of the number of independent directors on the analyzed bank performances. Regarding to our findings, it is emphasized that independent board affects positively bank performances, such as profitability and liquidity, while in the case of other bank performance indicators this characteristic has no significant influence. Consequently, the hypotheses H1 and $\mathrm{H} 2$ are partially accepted.

Therefore, it is possible to conclude that board structure represents an important determinant of bank performances. However, in the cases when significant influence of this independent variable on the observed dependent ones is not identified, it is necessary to identify the factors which influence optimal capital adequacy, assets quality, as well as the improvement of management efficiency. This is why it is necessary to continue with the research in this area that should include behavioral characteristics of board members as well as the competences of board members.

The contribution of the carried research reflects in filling out the identified gap, in order to provide the insight into the factors that determine bank performances. Namely, limited empirical studies on the influence of structural characteristics of board on bank performances using CAMELS model. Since CAMELS model provides comprehensive insight into the bank performances, the improvement in relation to the previous research is precisely reflected in the manner of measuring bank performances. Furthermore, the obtained results can be used for the improvement of corporate governance practice within banking sector.

Acknowledgement: This paper is part of an interdisciplinary research project (number 41010), financed by the Ministry of Education, Science and Technological Development of the Republic Serbia.

\section{REFERENCES}

Adams, R. B., \& Mehran, H. (2012). Bank board structure and performance: Evidence for large bank holding companies. Journal of financial Intermediation, 21(2), 243-267.

Aebi, V., Sabato, G., \& Schmid, M. (2012). Risk management, corporate governance, and bank performance in the financial crisis. Journal of Banking \& Finance, 36(12), 3213-3226.

Babić, V. M., Nikolić, J. D., \& Erić, J. M. (2011). Rethinking board role performance: Towards an integrative model. Economic Annals, 56(190), 140-162. 
Babić, V. M., Nikolić, J. D., \& Erić, J. M. (2012). Board structure and corporate performance: Traditional vs. Contemporary approach. In V. Babić (red.), Contemporary issues in economics, business and management, Ekonomski fakultet, Kragujevac, pp. 49-64

Bantel, K. A., \& Jackson, S. E. (1989). Top management and innovations in banking: Does the composition of the top team make a difference?. Strategic management journal, 10(S1), 107-124.

Barroso-Castro, C., Perinan, M. M., \& Dominguez, M. (2017). Board members' contribution to strategy: The mediating role of board internal processes. European Research on Management and Business Economics, 23(2), 82-89.

Belkhir, M. (2009). Board structure, ownership structure and firm performance: evidence from banking. Applied financial economics, 19(19), 1581-1593.

Beltratti, A., \& Stulz, R. M. (2012). The credit crisis around the globe: Why did some banks perform better?. Journal of Financial Economics, 105(1), 1-17.

Borokhovich, K. A., Parrino, R., \& Trapani, T. (1996). Outside directors and CEO selection. Journal of Financial and Quantitative Analysis, 31(3), 337-355.

Bushman, R. M., Piotroski, J. D., \& Smith, A. J. (2004). What determines corporate transparency?. Journal of accounting research, 42(2), 207-252.

Carter, D. A., Simkins, B. J., \& Simpson, W. G. (2003). Corporate governance, board diversity, and firm value. Financial review, 38(1), 33-53.

Cerbioni, F., \& Parbonetti, A. (2007). Exploring the effects of corporate governance on intellectual capital disclosure: an analysis of European biotechnology companies. European Accounting Review, 16(4), 791-826.

Daily, C. M., \& Dalton, D. R. (1992). The relationship between governance structure and corporate performance in entrepreneurial firms. Journal of Business Venturing, 7(5), 375-386.

Dang, U. (2011). The CAMEL rating system in banking supervision. A case study.Arcada University of Applied Sciences, International Business.

De Andres, P., \& Vallelado, E. (2008). Corporate governance in banking: The role of the board of directors. Journal of banking \& finance, 32(12), 2570-2580.

De Andres, P., Romero-Merino, M. E., Santamaría, M., \& Vallelado, E. (2012). Board determinants in banking industry. An international perspective. Managerial and Decision Economics, 33(3), 147-158.

De Haan, J., \& Vlahu, R. (2016). Corporate governance of banks: A survey. Journal of Economic Surveys, 30(2), 228-277.

Desta, T. S. (2016). Financial Performance of "The Best African Banks": A Comparative Analysis Through Camel Rating. Journal of Accounting and Management, 6(1), 1-20.

Eisenberg, T., Sundgren, S., \& Wells, M. T. (1998). Larger board size and decreasing firm value in small firms 1. Journal of financial economics, 48(1), 35-54

Erkens, D. H., Hung, M., \& Matos, P. (2012). Corporate governance in the 2007-2008 financial crisis: Evidence from financial institutions worldwide. Journal of Corporate Finance, 18(2), 389-411.

Fama, E. F., \& Jensen, M. C. (1983). Agency problems and residual claims. The Journal of Law and Economics, 26(2), 327-349.

Flannery, M. J. (1998). Using market information in prudential bank supervision: A review of the US empirical evidence. Journal of Money, Credit and Banking, 273-305.

Jackowicz, K., \& Kowalewski, O. (2012). Crisis, internal governance mechanisms and pension fund performance: Evidence from Poland. Emerging Markets Review, 13(4), 493-515.

Jadah, H. M., \& Adzis, A. B. A. (2016). The effect of board characteristics on Iraqi banks performance. International Journal of Academic Research in Accounting, Finance and Management Sciences, 6(4), 205-214.

Jensen, M. C. (1993). The modern industrial revolution, exit, and the failure of internal control systems. The Journal of Finance, 48(3), 831-880.

Kostyuk, A. (2011). Corporate governance in banking sector in transition economy: the role of ownership structures. Serbian Journal of Management, 6(1), 43-54.

Levine, R. (2004). The corporate governance of banks: A concise discussion of concepts and evidence. The World Bank.

Lipton, M., \& Lorsch, J. W. (1992). A modest proposal for improved corporate governance. The business lawyer, 59-77.

Macey, J. \& O’Hara, M., (2003). The corporate governance of banks. FRBNY Economic Policy Review, 91-107.

Minton, B. A., Taillard, J., \& Williamson, R. (2011). Do independence and financial expertise of the board matter for risk taking and performance?. http://citeseerx.ist.psu.edu/viewdoc/download?doi=10.1.1.688. $3550 \&$ rep=rep $1 \&$ type $=$ pdf 
Ongore, V. O., K’Obonyo, P. O., Ogutu, M., \& Bosire, E. M. (2014). Board composition and financial performance: Empirical analysis of companies listed at the Nairobi Securities Exchange. International Journal of Economics and Financial Issues, 5(1), 23-43.

Orazalin, N., Mahmood, M., \& Jung Lee, K. (2016). Corporate governance, financial crises and bank performance: lessons from top Russian banks. Corporate Governance: The International Journal of Business in Society, 16(5), 798-814.

Pathan, S. (2009). Strong boards, CEO power and bank risk-taking. Journal of Banking \& Finance, 33(7), $1340-1350$.

Pugliese, A., Bezemer, P., Zattoni, A., Huse, M., van den Bosch, F. A. J., \& Volberda, H. W. (2009). Boards of directors'contributions to strategy: A literature review and research agenda. Corporate Governance: An International Review, 17, 292-306.

Shungu, P., Ngirande, H., \& Ndlovu, G. (2014). Impact of corporate governance on the performance of commercial banks in Zimbabwe. Mediterranean Journal of Social Sciences, 5(15), 93.

Singh, M., \& Davidson III, W. N. (2003). Agency costs, ownership structure and corporate governance mechanisms. Journal of Banking \& Finance, 27(5), 793-816.

Staikouras, P. K., Staikouras, C. K., \& Agoraki, M. E. K. (2007). The effect of board size and composition on European bank performance. European Journal of Law and Economics, 23(1), 1-27.

Stančić, P., Čupić, M., \& Obradović, V. (2014). Influence of board and ownership structure on bank profitability: evidence from South East Europe. Economic research - Ekonomska istraživanja, 27(1), 573-589.

Vunjak, N., Davidović M., \& Stefanović, M. (2012). The Impact of The Global Financial Crisis on the Performances of the Serbian Banking Sector, TEME: Journal for Social Sciences, 36(3), 1279-1298.

Yermack, D. (1996). Higher market valuation of companies with a small board of directors. Journal of financial economics, 40(2), 185-211.

\section{STRUKTURA UPRAVNOG ODBORA I PERFORMANSE BANAKA: EVIDENCIJA IZ BANKARSKOG SEKTORA REPUBLIKE SRBIJE}

Tradicionalna perspektiva, zasnovana na agencijskog teoriji, počiva na pretpostavci da struktura upravnog odbora, kao internog mehanizma korporativnog upravljanja, determiniše njegovu efektivnost, a posledično i finansijske performanse korporacija. Veličina upravnog odbora, kompozicija i liderska struktura se izdvajaju kao relevantne varijable strukture odbora. Budući da su rezultati prethodnih empirijskih studija neretko oprečni, utvrđivanje međuzavisnosti između strukturnih karakteristika $i$ poslovnih performansi je relevantno istraživačko pitanje, posebno u slučaju bankarskog sektora. Kako bi se unapredila efektivnost internih mehanizama korporativnog upravljanja, a posledično, $i$ performansi banaka, glavni cilj istraživanja je identifikacija uticaja veličine i kompozicije upravnog odbora na performanse banaka u Republici Srbiji, upotrebom CAMELS modela. Analizirali smo međuzavisnost koristeći regresioni balansirani panel model, baziran na metodu najmanjih kvadrata, pri čemu je ukupan broj opservacija 54. Doprinos rada se ogleda u izvođenju zaključaka o efektima strukture upravnog odbora na finansijske performanse, kao osnove za definisanje preporuka za unapređenje finansijskih performansi u bankarskom sektoru.

Ključne reči: upravni odbor, struktura upravnog odbora, performanse, CAMELS, bankarski sektor, Republika Srbija 